
bacterium isolated from a marine sediment of Kongsfjorden, Svalbard

Sisinthy Shivaji, P. Vishnu Vardhan Reddy, S. S. S. Nageshwara Rao, Zareena Begum and T. N. R. Srinivas

International Journal of Systematic and Evolutionary Microbiology doi: 10.1099/ijs.0.024901-0. Published online ahead of print on 2 July 2010

The authors would like to retract this publication in order to improve the chemotaxonomic data as it has become apparent that there are inconsistencies in the data presented in this paper. This paper has been retracted from IJSEM Papers in Press and will not be published in print in IJSEM.

\title{
Oceanisphaera arctica sp. nov., isolated from a marine sediment of Kongsfjorden, Svalbard, Arctic
}

T. N. R. Srinivas, P. Vishnu Vardhan Reddy, Z. Begum and Sisinthy Shivaji

International Journal of Systematic and Evolutionary Microbiology doi: 10.1099/ijs.0.024539-0.

Published online ahead of print on 20 August 2010

The authors would like to retract this publication in order to improve the chemotaxonomic data as it has become apparent that there are inconsistencies in the data presented in this paper. This paper has been retracted from IJSEM Papers in Press and will not be published in print in IJSEM.

Cecembia lonarensis gen. nov., sp. nov., a novel haloalkalitolerant bacterium of the family Cyclobacteriaceae, isolated from a haloalkaline lake and emended descriptions of the genera Indibacter, Nitritalea, Belliella and Aquiflexum

P. Anil Kumar, T. N. R. Srinivas, S. Madhu, R. Sravan Kumar, S. Singh, S. W. A. Naqvi, S. Mayilraj and S. Shivaji

International Journal of Systematic and Evolutionary Microbiology doi: 10.1099/ijs.0.020297-0.

Published online ahead of print on 17 September 2010

The authors would like to retract this publication in order to improve the chemotaxonomic data as it has become apparent that there are inconsistencies in the data presented in this paper. This paper has been retracted from IJSEM Papers in Press and will not be published in print in IJSEM. 